\title{
HOAKS DI TEKNOLOGI INFORMASI DAN KOMUNIKASI DALAM HADITS
}

\author{
Rof-rof Galih Samudra \\ UIN Sulatan Maulana Hasanudin Banten \\ Email: rofrof.gs@gmail.com
}

\begin{abstract}
Hoax is a serious problem in information technology, namely in social media. The word hoax comes from the word hocuspocus which is originally Latin for hoc est corpus, meaning, this is the body. This word is commonly used by magicians to propose that something is true, but it is not necessarily true. according to KBBI, it is an upturned word, namely fake news or news without a source. It can be concluded that hoax is news that is untrue and has no source or basis which is used to deceive many people and believe in a news. To solve this problem the author tries to discuss the substance of hoaxes in this journal, as well as a mid-semester test for students in the ulumul interpretation course, with the literature study method by taking some references to strengthen the substance by quoting experts in their fields as well as online references and concluding at the end. journals, as for the outline of efforts to deal with hoaxes, are following the instructions of the Qur'an and Hadith, being honest in their words, and threatening untrue news.
\end{abstract}

Keyword: hoax, information, communication

\section{Abstrak}

Hoaks merupakan masalah serius didalam teknologi informasi yaitu dimedia sosial. Kata hoaks berasal dari kata hocuspocus yang aslinya merupakan bahasa latin hoc est corpus, berarti, ini adalah tubuh. Kata ini biasa digunakan oleh penyihir untuk mengajukan sesuatu hal adalah benar, tetapi belum tentu hal tersebut benar. menurut KBBI merupakan kata serapan yaitu berita bohong atau 
berita tidak bersumber.Dapat disimpulkan bahwa hoaks merupakan berita yang tidak benar dan tidak bersumber atau tidak berdasar yang digunakan untuk membuat banyak orang terperdaya dan mempercayai suatu berita. Untuk menyelesaikan masalah ini penulis berupaya membahas subtansi hoaks pada jurnal ini, serta menjadi ulangan tengah semester mahasiswa pada mata kuliah ulumul tafsir, dengan metode studi pustaka dengan mengambil beberapa refrensi untuk menguatkan subtansi dengan mengutip pakar-pakar pada bidangnya serta refrensi online dan menyimpulkan pada akhir jurnal, adapun garis besar terhadap upaya menangani hoaks ialah, mengikuti petunjuk Al-Qur'an dan Hadits, jujur dalam perkataan, serta mengencam berita yang tidak benar.

Kata kunci: hoaks, informasi, komunikasi

\section{Pendahuluan}

Dikatakan bahwa komunikasi merupakan hal terpenting bagi manusia, tanpa ada komunikasi manusia bisa saja tersesat dengan berkembangnya pengetahuan teknologi informasi dan komunikasi memudahkan manusia berkomunikasi dengan sangat mudah bukan hanya untuk berkomunikasi tetapi bisa dengan mudah juga mendapatkan informasi. Media sosial merupakan buah dari perkembangan teknologi informasi dan komunikasi yang berkembang menjadi diskusi public yang nyaris tidak memiliki batasan. Di sisi lain memberikan manfaat tetapi bisa juga menjerumuskan ketika informasi yang didapatkan tidak benar atau berita hoaks. ${ }^{1}$

Hoaks adalah fenomena yang tersebar di tengah-tengah masyarakat saat ini. Hoaks menjadi merajalela dimana-mana karena didukung oleh berbagai media sosial yang semakin berkembang, seperti Instagram, Facebook, Twetter, WhatsApp, Line, dan lain sebagainya. ${ }^{2}$ Hoaks dalam pengertiannya merupakan berita yang tidak benar dan tidak bersumber atau tidak berdasar yang digunakan untuk membuat banyak orang terperdaya dan mempercayai suatu berita. Didalam pengertiannya Hoaks merupakan perkataan dusta yang tidak sesuai dengan fakta yang ada dan Allah SWT tidak menyukai perilau tersebut. Dalam kehidupan sehari hari, kita sering mendengar desas desus yang tidak jelas asal usulnya. Kadang dari suatu peristiwa

${ }^{1}$ Idnan A Idris, Klarifikasi Al-Quran Atas Berita Hoaks, (Jakarta: Granmedia, 2018), 1,3,6.

${ }^{2}$ Siti Nur Khotimah, LARANGAN MENYEBARKAN HOAX DALAM AL-QUR'AN (Penafsiran QS. al-Nur Ayat 11-20 menurut Wahbah al-Zuhaily dalam Tafsir al-Munir ), (Surakarta, Universitas Muhammadiyah Surakarta, 2019), 2. 
kecil, tetapi dalam pemberitaannya, peristiwa itu begitu besar atau sebaliknya. Terkadang juga berita itu menyangkut kehormatan seorang muslim. Bahkan tidak jarang, sebuah rumah tangga menjadi retak, hanya karena sebuah berita yang belum tentu benar.

Bagaimanakah sikap kita terhadap berita yang bersumber dari orang yang belum kita ketahui kejujurannya? Hoaks atau fake news bukan sesuatu yang baru, dan sudah banyak beredar sejak Johannes Gutenberg menciptakan mesin cetak pada tahun 1439 . Sebelum zaman internet, hoaks bahkan lebih berbahaya dari sekarang karena sulit untuk diverifikasi. Apa itu hoax. Untuk menyikapi hoaks didalam Al-Qur'an dan Hadits telah dijelaskan dan akan dijelaskan didalam jurnal ini.

\section{A. Fenomena hoaks dalam teknologi informasi dan komunikasi ${ }^{3}$}

Kemunculan hoaks tidak lepas dari perkembangan teknologi informasi dan komunikasi yang telah mengubah alat-alat komunikasi menjadi lebih mudah untuk digunakan. Alat-alat komunikasi berpengaruh kepada berkembangnya media sosial. Perkembangan ini mengubah cara berkomunikasi antara masyarakat ataupun individu. Sebuah komunikasi dan informasi dapat dilakukan serta tersebar secara cepat, bahkan hampir tidak ada batasan tertentu, sehingga semua masyarakat bisa dengan bebas mengeluarkan pendapat. Semuanya menjadi lebih mudah dalam menerima, berbagi, dan memberi komentar melalui media sosial seperti Instagram, Facebook, Twetter, WhatsApp, Line, dan lain sebagainya. Kemudian, Semua informasi saling tumpuk, berimplosif, dan berekplosif, karena dibuat melalui berbagai cara seperti bagi atau share dan salin atau copy dalam media sosial.

Kebebasan mengeluarkan informasi atau berita secara tidak langsung menyebabkan banyak sekali berita hoaks yang bertujuan untuk membentuk opini publik, demi kepentingan tertentu. Berita hoaks bisa juga dipakai untuk saling menuduh, menyerang, dan melakukan stereotypes, bahkan bisa untuk menyatakan bahwa suatu kelompok atau agama tertentu lebih tinggi dibanding yang lainnya. Media sosial datang untuk menyampaikan informasi yang tidak bisa lepas dari banyaknya kepentingan sosial dan politik. Pada akhirnya, media sosial menjadi wadah untuk kepentingan berbagai pihak. Di satu sisi, media sosial juga sudah menjadi komoditas informasi untuk memenuhi kebutuhan dan

${ }^{3}$ Luthfi Maulana, "Kitab Suci dan Hoax: Pandangan Alquran dalam Menyikapi berita bohong", Wawasan: Jurnal Ilmiah Agama dan Sosial Budaya 2, 2 (Desember 2017), 211-212. 
keingintahuan masyarakat. Tetapi, di lain sisi media sosial juga lebih condong digunakan untuk kepentingan mendiskreditkan salah satu pihak demi keuntungan tertentu dan semua dilakukan itu tanpa memerhatikan bagaimana dampak sosial yang mungkin terjadi dimasa depan.

\section{B. Pengertian hoaks}

Kata hoaks berasal dari kata hocuspocus yang aslinya merupakan bahasa latin hoc est corpus, berarti, ini adalah tubuh. Kata ini biasa digunakan oleh penyihir untuk mengajukan sesuatu hal adalah benar, tetapi belum tentu hal tersebut benar. Hoax adalah informasi atau berita yang isinya berupa hal-hal yang belum pasti atau yang benar-benar bukan fakta yang tejadi. ${ }^{4}$

Hoaks menurut KBBI merupakan kata serapan yaitu berita bohong atau berita tidak bersumber. ${ }^{5}$ Hoaks didalam Bahasa inggri yaitu memperdaya banyak orang dengan sebuah berita bohong. ${ }^{6}$ Dapat disimpulkan bahwa hoaks merupakan berita yang tidak benar dan tidak bersumber atau tidak berdasar yang digunakan untuk membuat banyak orang terperdaya dan mempercayai suatu berita.

\section{Hoaks dalam Hadits}

Dalam hadits ada juga pembahasan dan penjelasan mengenai hoaks seperti hadits berikut:

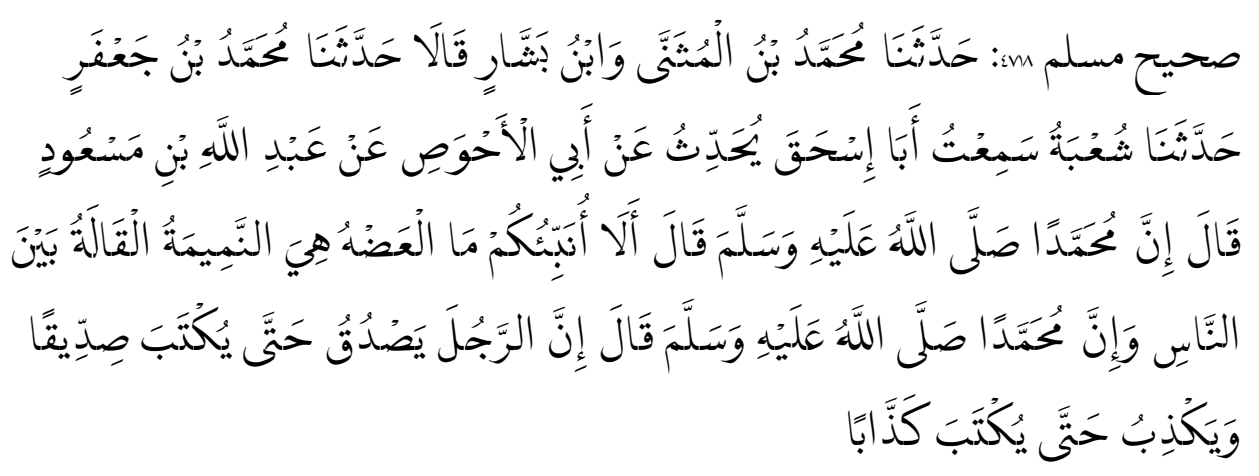

${ }^{4}$ Siti Nur Khotimah, "LARANGAN MENYEBARKAN HOAX DALAM AL-QUR'AN (Penafsiran QS. al-Nur Ayat 11-20 menurut Wahbah al-Zuhaily dalam Tafsir al-Munir )", 5.

${ }^{5}$ https://kbbi.kemdikbud.go.id/entri/hoaks

${ }^{6}$ Muh. Sadik Sabry dan Muhammad Darwis Ridwan, “WAWASAN AL-QUR'AN TENTANG HOAKS (Suatu Kajian Tafsir Tematik)' Tafsere Volume 6, Nomor 2, (2018), 45. 
Shahih Muslim 4718: Telah menceritakan kepada kami Muhammad bin Al Mutsanna dan Ibnu Basysyar keduanya berkata: Telah menceritakan kepada kami Muhammad bin Ja'far: Telah menceritakan kepada kami Syu'bah Aku mendengar Abu Ishaq bercerita dari Abu Al Ahwash dari 'Abdullah bin Mas'ud dia berkata: bahwa Muhammad shallallahu 'alaihi wa sallam bersabda: 'Perhatikanlah, aku akan memberitahukan kepada kalian apa itu Al 'Adhu? Al 'Adhu adalah memfitnah dengan menyebarluaskan isu di tengah masyarakat." Rasulullah shallallahu 'alaihi wa sallam juga bersabda: 'Sesungguhnya orang yang selalu berkata jujur akan dicatat sebagai seorang yang jujur dan orang yang selalu berdusta akan dicatat sebagai pendusta.'

Meskipun tidak disebutkan secara langsung tentang tukang fitnah/adu domba di dalam hadits di atas, namun di sana disebutkan pemahaman lain tentang tukang fitnah/adu- domba itu sebagai seorang yang selalu berdusta atau seorang pendusta, sebagaimana dikatakan dalam hadits tersebut. Dalam Bahasa Indonesia ada kaitan erat dalam soal pemahaman antara kaitan antara fitnah, adu domba dan dusta. ${ }^{7}$ Jadi hoaks dalam kata lain bisa disebut dengan fitnah, adu domba dan juga dusta tetapi bedanya hoaks munculnya didunia maya atau sosial media. Dalam hadits lain juga dijelaskan bagaimana hukum orang yang melakukan hoaks yaitu:

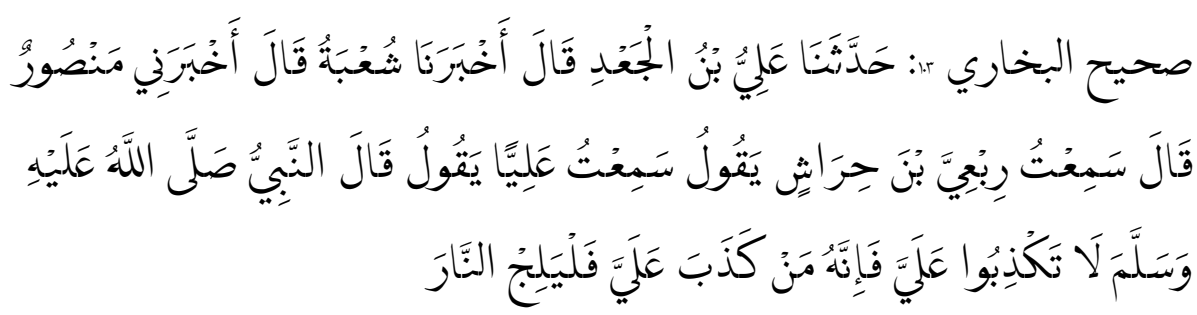

Shahih Bukhari 103: Telah menceritakan kepada kami 'Ali bin Al Ja'd berkata: telah mengabarkan kepada kami Syu'bah berkata: telah mengabarkan kepadaku Manshur berkata: aku mendengar Rib'i bin Jirasy berkata: aku mendengar 'Ali berkata: Nabi shallallahu 'alaihi wa sallam bersabda: "Janganlah kalian berdusta terhadapku (atas namaku), karena barangsiapa berduasta terhadapku dia akan masuk neraka."

Dalam hadits tersebut dikatakan bahwa orang yang melakukan dusta atau hoaks dalam dunia maya akan masuk kedalam neraka. Dan dalam

${ }^{7}$ Muhammad Thaef Ashshiddiqi, Hoax dalam Al-Quran, (Medan: Universitas Islam Negeri Sumatra Utara, 2019), hal 62. 
hadits lain juga dijelaskan masuk kedalam golongan mana orang yang melakukan hoaks yaitu:

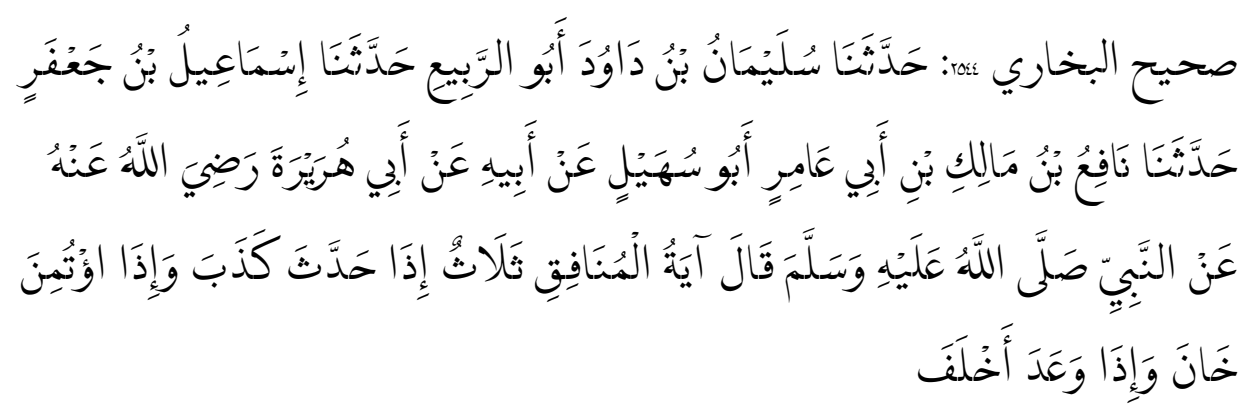

Shahih Bukhari 2544: Telah bercerita kepada kami Sulaiman bin Daud Abu Ar Rabi' telah bercerita kepada kami Isma'il bin Ja'far telah bercerita kepada kami Nafi' bin Malik bin Abi 'Amir Abu Suhail dari bapaknya dari Abu Hurairah radliyallahu 'anhu dari Nabi shallallahu 'alaihi wa sallam bersabda: "Tanda-tanda munafiq ada tiga, yaitu: jika berbicara berdusta, jika diberi amanat khiyanat dan jika berjanji ingkar."

Dalam hadits diatas menjelaskan bahwa berbicara dusta merupakan tanda-tanda dari orang munafik jadi bisa disumpulkan melakukan hoaks didalam sosial media juga menjadi tanda-tanda dari orang munafik.

\section{Sikap didalam Al-Qur'an dan Hadits terhadap hoaks}

Meninjau dari Banyaknya dampak yang timbul oleh hoaks, karena hal tersebut sikap terhadap hoaks menjadi sangat penting. ${ }^{8}$ Menanggapi hal tersebut, peran Al-Qur'an dan Hadits sebagai petunjuk umat manusia, Alquran telah mengatur berbagai hal, terlebih dalam menyikapi dan meminimalisir peredaran hoaks yang sangat meresahkan, inilah beberapa hal dalam Al-Qur'an terkait upaya meminimalisir peredaran hoaks yaitu sebagaimana berikut:

a. Al-Qur.an menganjurkan untuk selalu berkata benar atau jujur

Al-Qur'an menjelaskan kepada umat manusia agar selalu berkata benar, terutama dalam menyampaikan sebuah berita, karena dengan menyampaikan sebuah berita yang benar, akan menjaga kebenaran suatu infoprmasi dan akan melahirkan keharmonisan dalam pergaulan.

${ }^{8}$ Muh. Sadik Sabry dan Muhammad Darwis Ridwan, "WAWASAN AL-QUR'AN TENTANG HOAKS (Suatu Kajian Tafsir Tematik)", 55. 
Sebagaimana dijelaskan dalam Al-Qur;an dalam Surat al-Ahzab ayat 70-72 tentang keharusan untuk menyampaikan kebenaran.

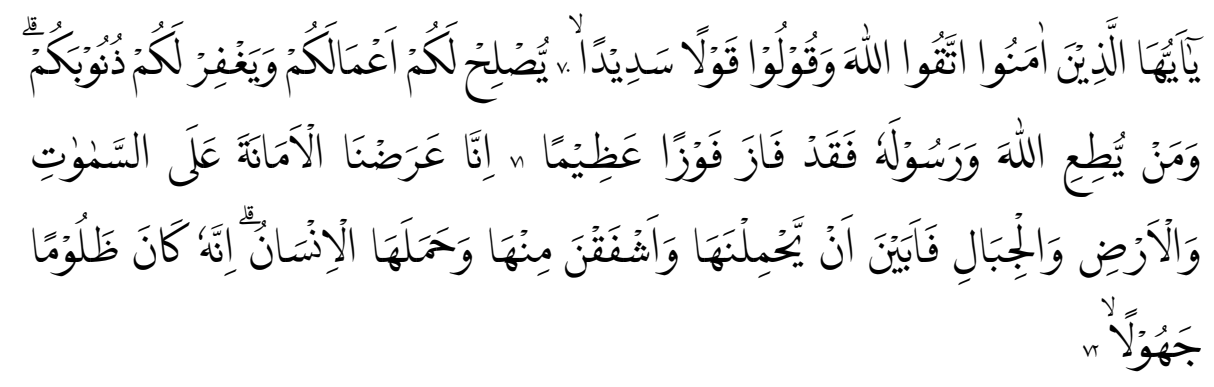

70. Wahai orang-orang yang beriman! Bertakwalah kamu kepada Allah dan ucapkanlah perkataan yang benar,

71. niscaya Allah akan memperbaiki amal-amalmu dan mengampuni dosa-dosamu. Dan barangsiapa menaati Allah dan Rasul-Nya, maka sungguh, dia menang dengan kemenangan yang agung.

72. Sesungguhnya Kami telah menawarkan amanat kepada langit, bumi dan gunung-gunung; tetapi semuanya enggan untuk memikul amanat itu dan mereka khawatir tidak akan melaksanakannya (berat), lalu dipikullah amanat itu oleh manusia. Sungguh, manusia itu sangat zalim dan sangat bodoh,

Maksud dari ayat tersebut adalah Allah SWT memberikan peringatan kepada umat manusia, bahwa takutlah kalian manusia jika melakukan maksiat (berkata dusta dalam menyampaikan berita), karena dengan melakukan maksiat (menyampaikan berita dengan dusta), maka Allah SWT akan memberikan hukuman, ayat ini juga merupakan seruan kepada umat manusia agar berkata dengan perkataan yang lurus, artinya dalam menyampaikan sebuah berita atau informasi harus disampaikan dengan benar dan tidak menyimpang, sehingga berita tersebut tidak menimbulkan kebatilan, dengan berkata yang benar, maka Allah SWT akan memberikan petunjuk menuju jalan yang benar dan terang benderang.

b. Bertabayyun Setiap Menerima Berita

Setiap menerima berita harus mengklarifikasi atau bertabayyun terlebih dahulu sebelum mempercayainya. Al-Qur'an mewajibkan umat Islam untuk melakukan tabayyun didalam QS. Al-Hujurat ayat 6.

Ayat tersebut merupakan anjuran agar berhati-hati dalam menerima berita yang didapat dari orang fasik. Ayat tersebut juga 
menuntut agar selalu berhati-hati dalam menyampaikan berita ataupun menjalani kehidupan sehari-hari. ${ }^{9}$

c. Periksalah Kebenaransebuah Informasi dengan Cermat

Allah Ta'ala punmemerintahkan kepada kita untuk memeriksa suatu informasi terlebih dahulukarena belum tentu semua informasi itu benar dan valid. Allah Ta'ala berfirman,

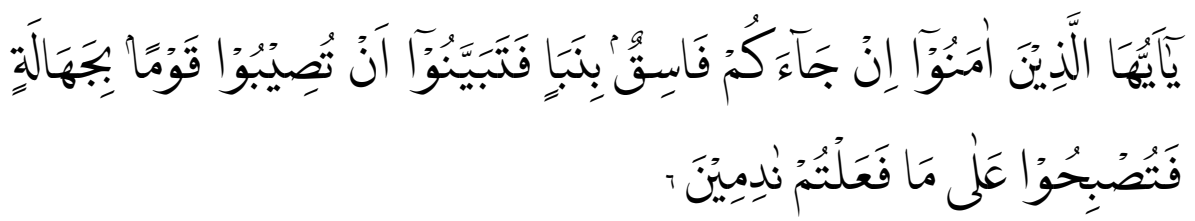

"Wahai orang orang yang beriman, jikadatang kepadamu orang fasik membawa suatu informasi, maka periksalah denganteliti, agar kamu tidak menimpakan suatu musibah kepada suatu kaum tanpamengetahui keadaannya yang menyebabkan kamu menyesal atas perbuatanmu itu."(QS. Al Hujuraat [49]: 6)

Allah Ta'ala memerintahkankita untuk memeriksa suatu informasi dengan teliti, yaitu mencari bukti buktikebenaran informasi tersebut. Hal ini bisa dilakukan dengan menelusuri sumber informasi,atau bertanya kepada orang yang lebih mengetahui hal itu.

Oleh karena itu, sungguh saat ini kita sangat perlu memperhatikan ayat ini. Suatu zaman di mana kita mudah untuk men share suatu link informasi, entah informasi dari status facebook teman, entah informasi online, dan sejenisnya, lebih lebih jika informasi tersebut berkaitan dengan kehormatan saudara muslim atau informasi yang menyangkut kepentingan masyarakat secara luas. Betapa sering kita jumpai, suatu informasi yangdengan cepat menjadi viral di media sosial, di share oleh ribuan netizen,namun belakangan diketahui bahwa informasi tersebut tidak benar.Sayangnya, klarifikasi atas informasi yang salah tersebut justru sepi dari peminformasian.

d. Bertanyalah, AdakahManfaat Menyebarkan suatu Informasi Tertentu?

Lalu, apabila kita sudahmemastikan keberannya, apakah informasi tersebut akan kita sebarkan begitusaja? Jawabannya tentu saja tidak. Akan tetapi, kita lihat terlebih dahuluapakah ada manfaat dari menyebarkan informasi (yang terbukti benar) tersebut?

Jika tidak ada manfaatnyaatau bahkan justru berpotensi menimbulkan salah paham, keresahan atau kekacauandi tengah tengah

${ }^{9}$ Luthfi Maulana, "Kitab Suci dan Hoax: Pandangan Alquran dalam Menyikapi berita bohong", 216-219. 
masyarakat dan hal hal yang tidak diinginkan lainnya, makahendaknya tidak langsung disebarkan (diam) atau minimal menunggu waktu dankondisi dan tepat. Rasulullah shallallahu'alaihi wa sallam bersabda,

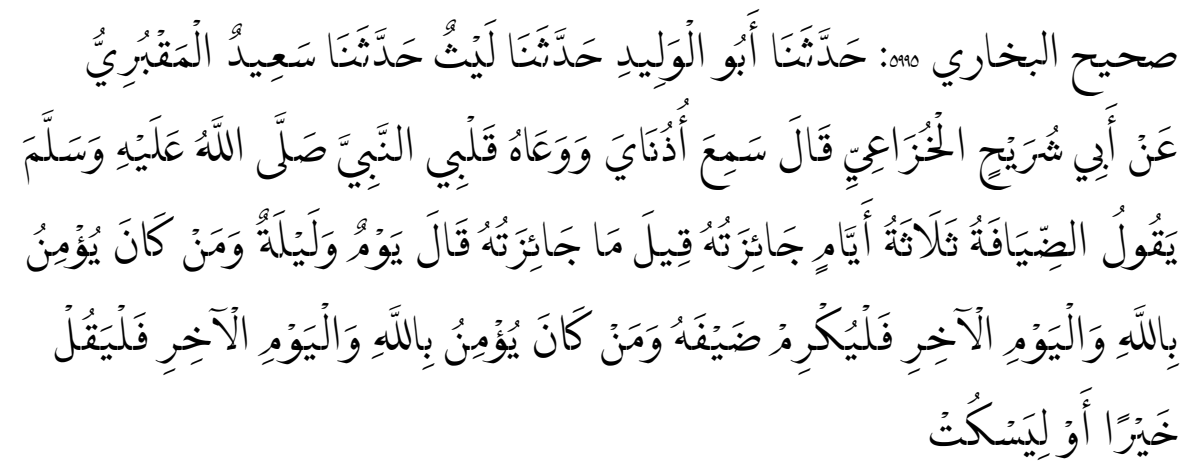

Shahih Bukhari 5995: Telah menceritakan kepada kami Abu Al Walid telah menceritakan kepada kami Laits telah menceritakan kepada kami Sa'id Al Maqburi dari Abu Syuraih Al Khuza'i dia berkata: "Aku telah mendengar dengan kedua telingaku dan meresap dalam hatiku ketika Nabi shallallahu 'alaihi wa sallam bersabda: "Bertamu itu tiga hari dengan menjamunya, " beliau di tanya: 'Apa yang di maksud dengan menjamunya?" beliau menjawab: "yaitu pada siang dan malam harinya. Barang siapa beriman kepada Allah dan hari akhir, hendaknya dia memuliakan tamunya, dan barangsiapa beriman kepada Allah dan hari Akhir hendaknya berkata baik atau diam."

e. Al-Qur'an Mengecam Keras Penyebar Berita Bohong

Al-Qur'an sangat mengecam orang-orang yang ikut dalam penyebaran berita bohong atau hoaks, baik dengan keadaan sadar ataupun tidak sadar dalam menyebarkannya. Hal ini ditegaskan dalam QS. an-Nur 24: 14-15.

${ }^{10}$ https://dalamislam.com/hukum-islam/hukum-menyebar-berita-hoaxdalam-islam 


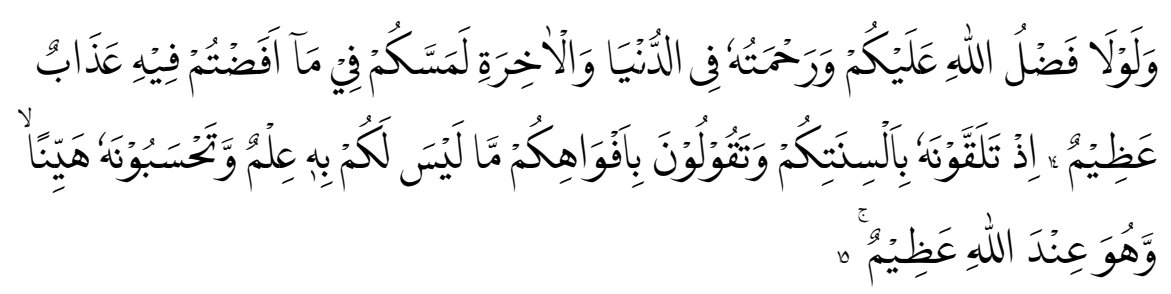

14. Dan seandainya bukan karena karunia Allah dan rahmat-Nya kepadamu di dunia dan di akhirat, niscaya kamu ditimpa azab yang besar, disebabkan oleh pembicaraan kamu tentang hal itu (berita bohong itu).

15. (Ingatlah) ketika kamu menerima (berita bohong) itu dari mulut ke mulut dan kamu katakan dengan mulutmu apa yang tidak kamu ketahui sedikit pun, dan kamu menganggapnya remeh, padahal dalam pandangan Allah itu soal besar.

Kedua ayat ini memberitahukan bahwa Allah SWT tidak akan menganugrahkan rahmat dan karunianya kepada orang-orang yang ikut terlibat didalam menyebarkan berita bohong atau hoaks. Jika tidak segera untuk bertaubat dan mengakui kesalahannya, maka Allah SWT akan memberikan azab yang besar kepada orang-orang tersebut. Allah SWT menegaskan, Jika menyebarkan berita bohong dan menganggap itu adalah perkara yang ringan, maka Allah SWT menganggapnya sebagai urusan yang besar, karena penyebarannya dapat merugikan berbagai pihak. ${ }^{11}$

\section{Kesimpulan}

Kata hoaks berasal dari kata hocuspocus yang aslinya merupakan bahasa latin hoc est corpus, berarti, ini adalah tubuh. Kata ini biasa digunakan oleh penyihir untuk mengajukan sesuatu hal adalah benar, tetapi belum tentu hal tersebut benar. Hoaks menurut KBBI merupakan kata serapan yaitu berita bohong atau berita tidak bersumber, Istilah berita bohong atau hoaks didalam hadits Meskipun tidak disebutkan secara langsung tentang tukang fitnah/adu domba di dalam hadits, namun di sana disebutkan pemahaman lain tentang tukang fitnah/adu- domba itu sebagai seorang yang selalu berdusta atau seorang pendusta, Untuk menyikapi masalah ini kita harus selalu berkata yang jujur, bertabayyun dalam

${ }^{11}$ Luthfi Maulana, "Kitab Suci dan Hoax: Pandangan Alquran dalam Menyikapi berita bohong", 216-219. 
menanggapi berita yang kita dapat dan juga memiliki kesadaran untuk mengencam berita-berita yang tidak benar.

\section{DAFTAR PUSTAKA}

Ashshiddiqi, Muhammad Thaef. Hoax dalam Al-Quran, (Medan: Universitas Islam Negeri Sumatra Utara, 2019), hal 62.

https://dalamislam.com/hukum-islam/hukum-menyebar-berita-hoaxdalam-islam

https://kbbi.kemdikbud.go.id/entri/hoaks

Idris, Idnan A. Klarifikasi Al-Quran Atas Berita Hoaks, Jakarta: Granmedia, 2018.

Khotimah, Siti Nur. LARANGAN MENYEBARKAN HOAX DALAM ALQUR'AN (Penafsiran QS. al-Nur Ayat 11-20 menurut Wahbah alZuhaily dalam Tafsir al-Munir ), Surakarta, Universitas Muhammadiyah Surakarta, 2019

Maulana, Luthfi. "Kitab Suci dan Hoax: Pandangan Alquran dalam Menyikapi berita bohong", Wawasan: Jurnal Ilmiah Agama dan Sosial Budaya 2, 2 (Desember 2017)

Sabry, Muh. Sadik dan Muhammad Darwis Ridwan. "WAWASAN ALQUR'AN TENTANG HOAKS (Suatu Kajian Tafsir Tematik)' Tafsere Volume 6, Nomor 2, (2018), 